\title{
Investigation of Effect of Aluminium Oxide Nanoparticles on the Thermal Properties of Water-Based Fluids in a Double Tube Heat Exchanger
}

\author{
Sajjad Porgar $1, * \mathbb{(})$, Nejat Rahmanian ${ }^{2(\mathbb{C}}$ \\ 1 Department of Chemical Engineering, South Tehran Branch, Islamic Azad University, Tehran, Iran; \\ sajjad.porgar@gmail.com (S.P.); \\ 2 Department of Chemical Engineering, Faculty of Engineering \& Informatics, University of Bradford, Bradford, BD7 1DP, \\ United Kingdom; N.Rahmanian@bradford.ac.uk (N.R.); \\ * Correspondence: sajjad.porgar@gmail.com (S.P.);
}

Received: 11.05.2021; Revised: 8.06.2021; Accepted: 11.06.2021; Published: 24.06.2021

\begin{abstract}
The thermal behavior of aluminium oxide-water nanofluid in a double pipe carbon steel heat exchanger was investigated in the present study. The overall heat transfer coefficient, Nusselt, and heat transfer coefficient of nanofluid were compared with the base fluid. The volume fraction of the nanoparticles was $1 \%$. By adding nanoparticles to the fluid, the thermal properties of the base fluid improved significantly. The hot and cold fluid flow was considered counter-current, and the nanofluid was pumped into the inner tube and once into the outer tube, and the flow rate of each fluid was 0.05 $\mathrm{kg} / \mathrm{s}$. The convective heat transfer and the overall heat transfer coefficient enhanced $94 \%$ and $253 \%$ for the hot fluid flow in the outer tube and $308 \%$ and $144 \%$ for the hot fluid flow in the inner tube, respectively. The pressure drop calculations also showed that the pressure drop would not change significantly when using nanofluid.
\end{abstract}

Keywords: nanofluid; thermal properties; heat exchanger; aluminium oxide.

(C) 2021 by the authors. This article is an open-access article distributed under the terms and conditions of the Creative Commons Attribution (CC BY) license (https://creativecommons.org/licenses/by/4.0/).

\section{Introduction}

Water, oil, and ethylene glycol are conventional heat transfer fluids used in various industries and processes with poor thermal properties. Increasing the thermal conductivity is a key idea for improving the thermal conductivity of conventional fluids. Since solid particles have a higher thermal conductivity than the base fluid, it is expected that suspension of fine particles in the base fluid will improve the thermal conductivity.

Nanofluids are prepared by dispersing nanoparticles into base fluids and nanoparticles are divided into different categories in different studies depending on their morphology, size and chemical properties. Metal oxide, carbon nanomaterials and nanocomposites are used in various industries. Magnetic nanoparticles are another group of nanomaterials made up of magnetic elements such as iron, cobalt, nickel, or oxides. Nanocomposites are materials whose nanoparticles are integrated into their lattice to improve the specific properties of materials $[1,2]$.

One of the simplest and most common methods for the production of metal nanoparticles is the reduction of metal salts. Different types of nanoparticles such as Rh, Os, $\mathrm{Pt}, \mathrm{Cu} \mathrm{Pd}, \mathrm{Au}, \mathrm{Ag}$ and Ir have been synthesized using this method. Carbon nanomaterials 
(carbon nanotubes, graphene, activated carbon, etc.) are another group of nanomaterials that due to high electrical and thermal conductivities, tensile strength and flexibility, have received much attention in various studies $[3,4]$.

Conventional synthesis methods are chemical vapor deposition, laser evaporation of carbon nanotubes, sonochemical arc discharge and hydrothermal, each of which has its advantages and disadvantages. Appropriate methods after the synthesis process must purify carbon nanotubes. The choice of nanotube synthesis and purification method is an important parameter that greatly impacts product quality and is based on the type and application required of this material [5]. The thermophysical properties of nanofluids include thermal conductivity, viscosity, density and heat capacity, which depend on the concentration, temperature and nature of the base fluid and nanoparticles, shown in Figure 1.

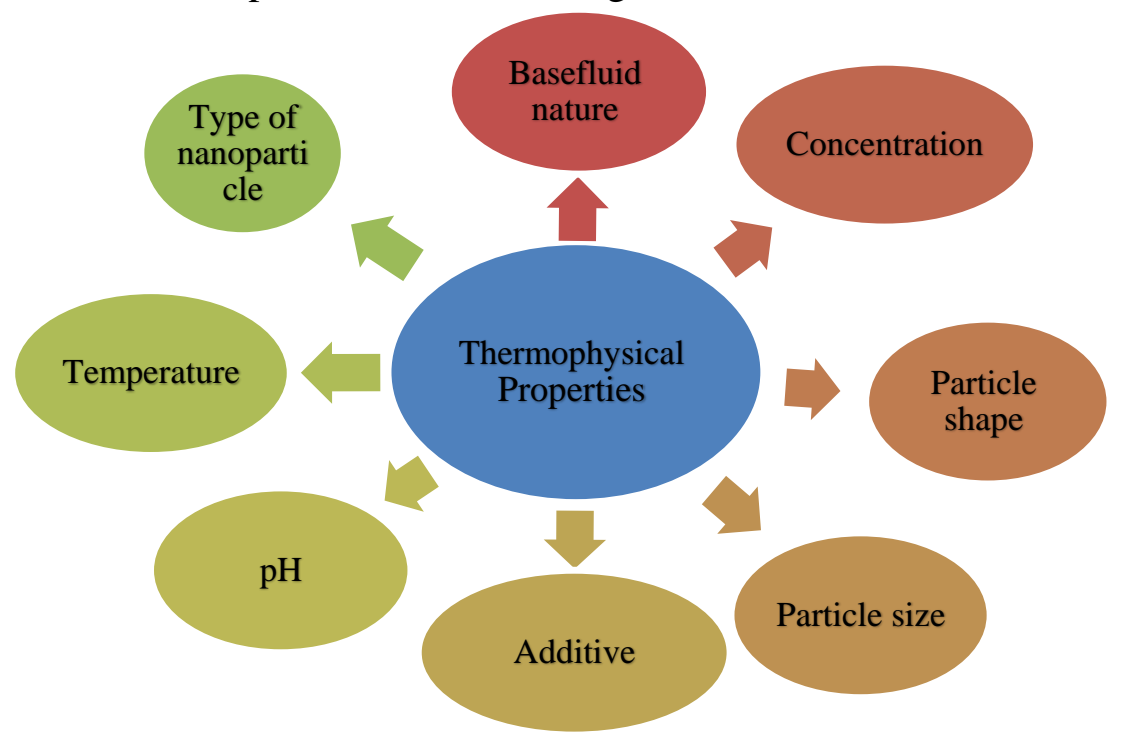

Figure 1. Parameters affecting thermophysical properties [6-9].

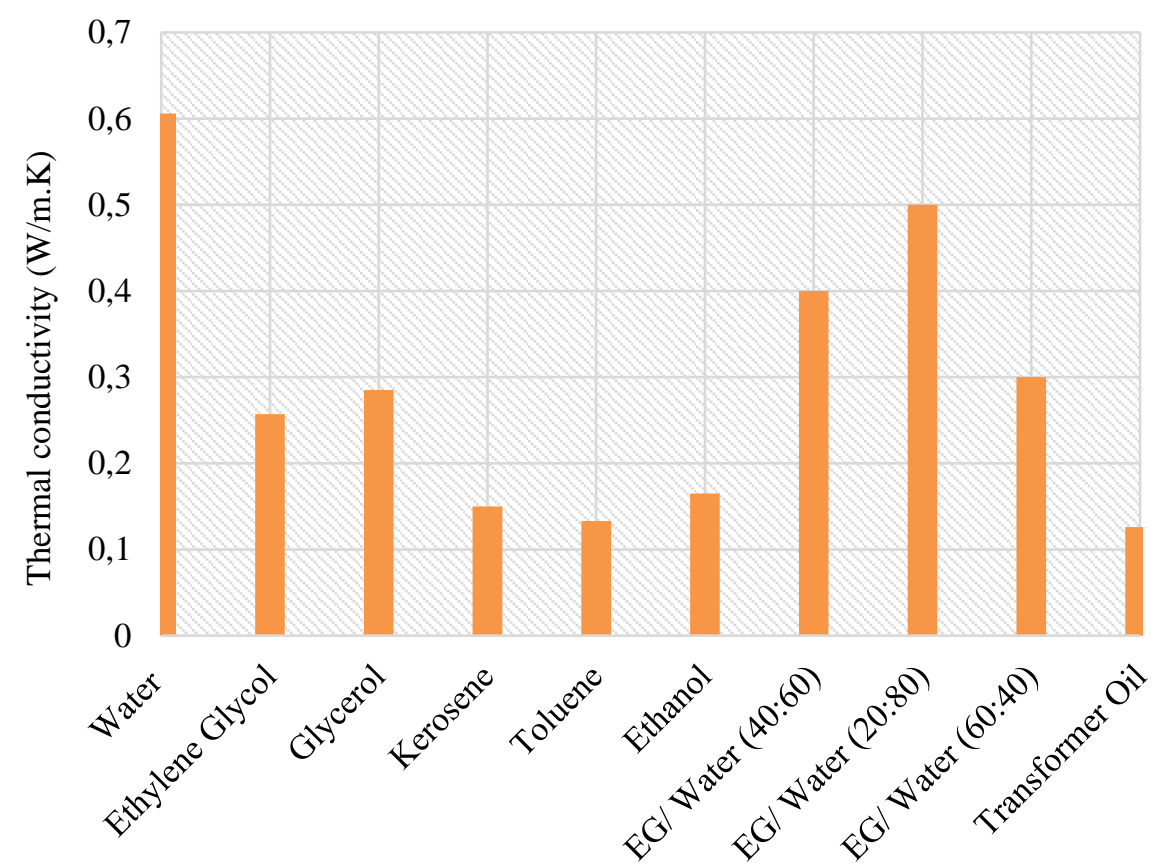

Figure 2. Thermal conductivity of base fluids [10]. 
The point that should be considered about nanofluids is that the existing models and relationships for nanofluids are limited to the same nanofluid and the same range and can not be generalized. Therefore, in this research, information about nanofluids has been collected.

Many researchers have reported that heat performance increases with nanofluids because nanoparticles are materials with higher thermal properties than base fluids, which, when added to them, increase nanofluids' thermophysical properties except heat capacity. The thermal conductivity of the base fluid is plotted in Figure 2. Figure 3 shows the effect of temperature in changing the thermal conductivity of the base fluids. It is clear from Figure 3 that by increasing the temperature, the thermal conductivity of base fluid increased. As shown in Figure 2, the thermal conductivity of water is higher than other fluids, and therefore the enhancement in thermal conductivity of water is also greater. The temperature has a positive effect on all fluids and, in all cases, increases the thermal conductivity.

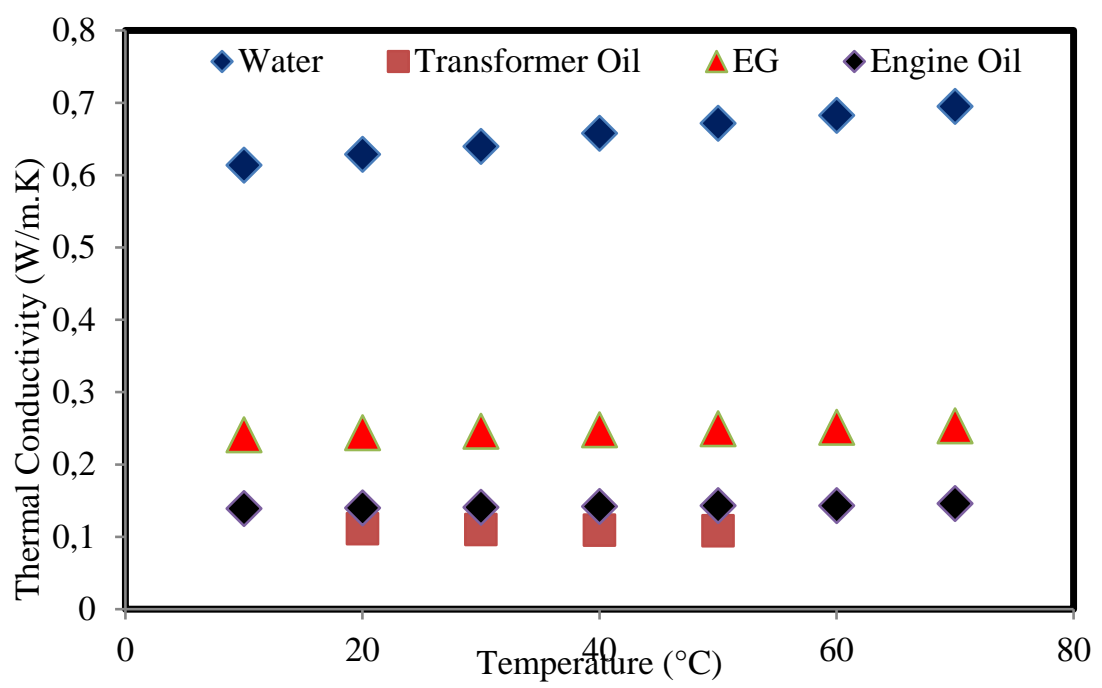

Figure 3. Temperature effect on thermal conductivity of different base fluids $[11,12]$.

Nanoparticles have a higher thermal conductivity than base fluids, which is much higher than base fluids. Figure 4 shows a comparison of the thermal conductivity values of common nanoparticles in various studies.

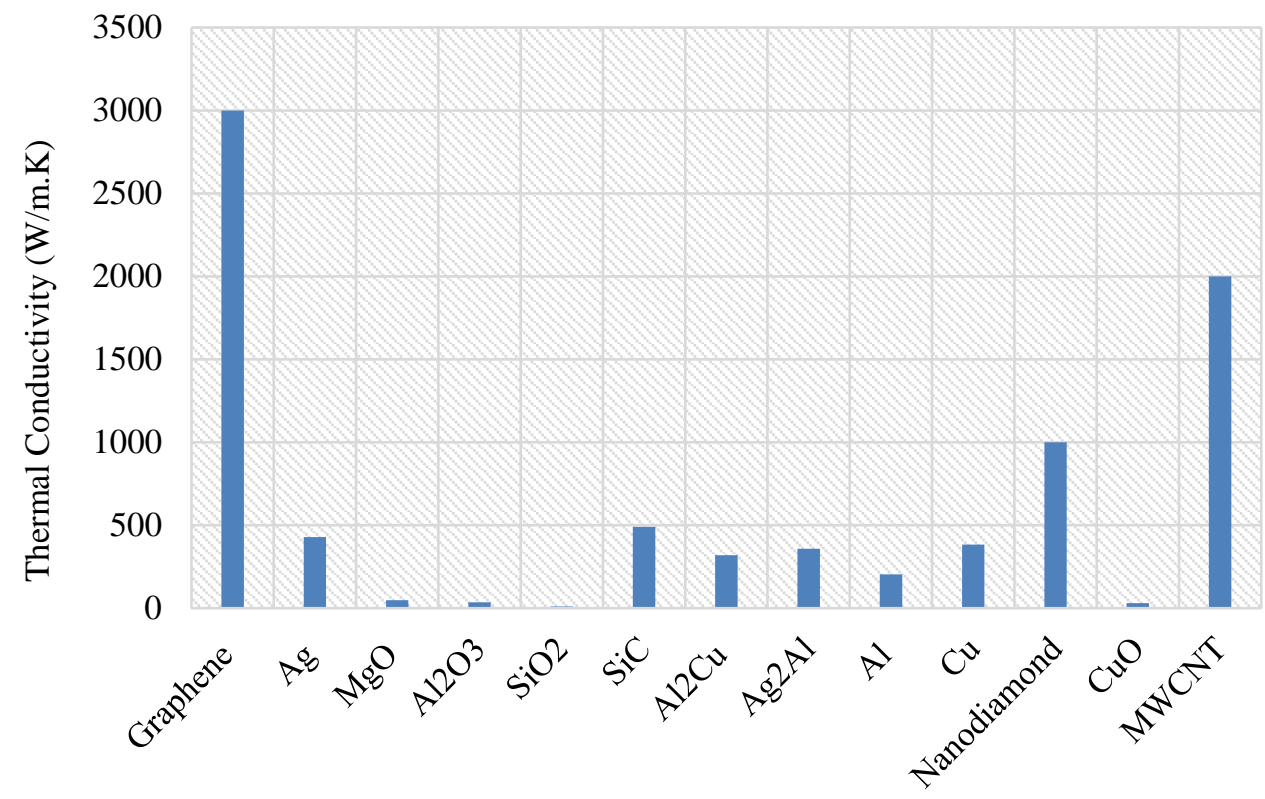

Figure 4. Comparison of thermal conductivity of nanoparticles. 
The thermal conductivity coefficient, as compared to other thermophysical properties, has been paid more attention by several researchers. Different empirical relationships and theories have been presented for different nanofluids in different ranges. Influential parameters in thermal conductivity include temperature, concentration, shape size, $\mathrm{pH}$ effect in nanofluid, surfactant, ultrasonic fluctuations, particle clustering effect and magnetic field effect. According to a study conducted by Dos et al., the temperature and concentration of nanoparticles have the most effect [13]. Table 1 provides an overview of research on the thermal conductivity of nanofluids.

Table 1. Overview of parameters and nanofluids preparation.

\begin{tabular}{|c|c|c|c|c|c|}
\hline Ref. & $\begin{array}{l}\text { Base } \\
\text { fluid }\end{array}$ & Particle & Size (nm) & Preparation method & $\begin{array}{c}\text { Enhan. } \\
\text { K }(\%)\end{array}$ \\
\hline$[14]$ & Vegetable oil & $\mathrm{Cu}-\mathrm{Zn}$ & $19,23,25$ & $\begin{array}{c}\text { The samples were sonicated for } \\
\text { three hours .Nanofluid was } \\
\text { stable for } 3 \text { days }\end{array}$ & 130 \\
\hline$[15]$ & Water /EG & $\mathrm{Al}_{2} \mathrm{O}_{3} / \mathrm{CuO}$ & $\begin{array}{c}\mathrm{CuO}: 29 \\
\mathrm{Al}_{2} \mathrm{O}_{3}: 40\end{array}$ & $\begin{array}{c}\text { Sonication time was } 16 \mathrm{~h} \text { and } \\
\text { nanofluid was prepared by two } \\
\text { step method }\end{array}$ & 90 to 95 \\
\hline$[16]$ & $\begin{array}{c}\text { DI } \\
\text { water, EG }\end{array}$ & MWCNT & 30 to 40 & $\begin{array}{c}\text { Nanofluid was sonicated for } 1 \\
\mathrm{~h}\end{array}$ & 90 \\
\hline$[17]$ & EG & Boron nitrid & 1 & ultrasonic agitation for $200 \mathrm{~min}$ & 260 \\
\hline$[18]$ & PAO & MWCNTs & - & $\begin{array}{l}\text { Ultrasonication and surfactant } \\
\text { were used to stabilize }\end{array}$ & 6 to 200 \\
\hline [19] & PAO & MWCNTs & $10-15$ & $\begin{array}{c}\text { Ultrasonication and } \\
\text { functionalization were used }\end{array}$ & 33 to 160 \\
\hline$[20]$ & Oil & MWCNTs & - & Ultra sonication and dispersant & 175 \\
\hline$[21]$ & Oil & MWCNT & $25 \times 50,000$ & - & 160 \\
\hline \multirow{2}{*}[22]{} & Water & $\mathrm{Al}_{2} \mathrm{Cu}$ & 31 & - & 106 \\
\hline & Water & $\mathrm{Ag}_{2} \mathrm{Al}$ & - & - & 150 to 210 \\
\hline \multirow{2}{*}{ [23] } & EG & $\mathrm{Al}-\mathrm{Cu}$ & 0 to 20 & - & 125 \\
\hline & Water & $\mathrm{Al}_{2} \mathrm{O}_{3}$ & 10 & - & 100 \\
\hline [24] & Kerosene & $\mathrm{Fe}_{3} \mathrm{O}_{4}$ & 6.7 & - & 300 \\
\hline [25] & Oil & MWCNT & - & - & 150 \\
\hline [26] & Water & MWCNT & - & - & 150 \\
\hline [27] & Water & MWCNT & - & - & 287 \\
\hline
\end{tabular}

Moldoveanu et al. studied $\mathrm{Al}_{2} \mathrm{O}_{3}-\mathrm{TiO}_{2}$ on the water-based fluid in the range of shear rate between 10-1000 (1/s) at ambient temperature and volume fraction between $1-5 \%$ and reported all samples showed non-Newtonian behavior. Finally, they presented three experimental models for the viscosity of $\mathrm{TiO}_{2}, \mathrm{Al}_{2} \mathrm{O}_{3}$, and $\mathrm{TiO}_{2}+\mathrm{Al}_{2} \mathrm{O}_{3}$ hybrid at ambient temperature as a function of concentration [28].

$\mathrm{Al}_{2} \mathrm{O}_{3}$ nanofluid: $\mathrm{\eta}_{r}=\frac{\mathrm{n}_{n f}}{\mathrm{n}_{f}}=0 / 6152 \varphi^{2}-1 / 5448 \varphi+2 / 3792$ and $R^{2}=1$

$\mathrm{TiO}_{2}$ nanofluid: $\eta_{r}=\frac{\eta_{n f}}{\eta_{f}}=0 / 2302 \varphi^{2}-0 / 3202 \varphi+1.5056$ and $R^{2}=1$

$\mathrm{TiO}_{2}+\mathrm{Al}_{2} \mathrm{O}_{3}$ nanofluid:

$\eta_{r}=\frac{\eta_{n f}}{\eta_{f}}=\frac{0}{3371 \varphi^{2}}-\frac{0}{1011 \varphi}+1.2921$ and $R^{2}=$

Sarafraz et al., in their research, investigated the heat transfer coefficient and pressure drop in the heat exchanger by using functionalized carbon nanotube nanoparticles on water base fluid at a concentration between 0.1-0.3\%wt. Their results showed that the heat transfer coefficient increased $56 \%$ at a mass fraction of 0.3 and also, the heat exchanger performance using nanofluid showed a 44\% improvement in the Reynolds number between 900-10500 [29]. Aghayari et al. studied the heat transfer coefficient and Nusselt number in a double-tube heat 
exchanger using $\mathrm{Al}_{2} \mathrm{O}_{3}$ nanofluid on a water-based fluid in their research. The volume fraction was between 0.1-0.3 and showed an enhancement in heat transfer coefficient of about $19 \%$ and a Nusselt number of $24 \%$. Their results also showed that the heat transfer coefficient increases with increasing temperature and volume fraction of nanoparticles [30]. In a similar study, Walvekar et al. examined the heat transfer coefficient of water nanofluid - carbon nanotubes in the weight fraction range of 0.05-0-085 and observed an enhancement of 9 to $67 \%$ in the heat transfer coefficient and temperature and weight fraction introduced as parameters that affect on heat transfer coefficient [31]. Chavda investigated the heat transfer coefficient of $\mathrm{CuO}$-water nanofluid in weight fractions of $0.002,0.003$, and 0.004 and prepared nanofluid in a two-steps method and studied the role of weight fraction in increasing the heat transfer coefficient in a double-tube heat exchanger [32]. Peyghambarzadeh et al. studied $\mathrm{CuO} /$ water and $\mathrm{AL}_{2} \mathrm{O}_{3}$ /water nanofluids in Reynolds between 500-2000 and reported a 49\% improvement in volume fraction for 0.1 for $\mathrm{AL}_{2} \mathrm{O}_{3} /$ water and a $27 \%$ enhancement in heat transfer coefficient at 0.2 for $\mathrm{CuO} /$ water [33]. Yang et al. experimentally studied the heat performance of watergraphite nanofluid transfer in a tubular heat exchanger. They reported that the heat transfer coefficient increased with increasing the weight fraction of nanoparticles. However, its value is less than the previous values [34]. In another study, Porgar et al. investigated the MWCNTs nanoparticles on transformer oil base fluid in a copper heat exchanger and obtained the thermophysical and thermal properties of the nanofluid as a function of temperature and concentration. They reported that with increasing temperature and concentration, the thermal performance of the nanofluid improved and the average improvement of thermal conductivity of nanofluid and overall heat transfer coefficient was $138 \%$ and $37.2 \%$ at $45{ }^{\circ} \mathrm{C}$ and concentration of $0.8 \mathrm{wt} \%$, respectively [35].

A review also has been done on nanofluids and investigated their important parameters that affect thermal performance. The results have shown in Table 2.

Table 2. Summarized nanofluid heat performance.

\begin{tabular}{|c|c|c|c|c|c|}
\hline Ref. & Basefluid & Particle & $\begin{array}{l}\text { Temperature } \\
\left({ }^{\circ} \mathbf{C}\right)\end{array}$ & Concentration & Remark \\
\hline [36] & $\begin{array}{l}\text { EG/ Water } \\
(60 / 40)\end{array}$ & $\begin{array}{l}\mathrm{ZnO}-\mathrm{MgO} \\
\text { hybrid }\end{array}$ & $30-80$ & $\begin{array}{c}0 \%, \\
0.0125 \%, 0.025 \\
\%, 0.05 \%, \\
0.075 \% \text { and } \\
0.1 \%\end{array}$ & $\begin{array}{c}\text { Surfactant: CTAB } \\
\text { h improvement: } 28.9 \% \\
\text { sythensize method: co-precipitation \& sol-gel }\end{array}$ \\
\hline [37] & EG & $\begin{array}{l}\text { SiC- } \\
\text { MWCNTs }\end{array}$ & $20-50$ & Up to 0.4 vol. $\%$ & $\begin{array}{c}\text { K improvement: } 32.01 \% \\
\text { Nanofluid showed Newtonian behaviour }\end{array}$ \\
\hline [38] & Water & $\mathrm{Ag}-\mathrm{TiO}_{2}$ & $20-45$ & $0.01,0.05,0.1 \%$ & $\begin{array}{l}\text { Ultrasonication was used to stabilize nanofluid } \\
\text { Overal heat transfer coefficient enhanced to } 2727.38 \\
\mathrm{~W} / \mathrm{m}^{2} \mathrm{~K} \\
\text { Nanofluid thermal conductivity increaesd to } 1.84 \mathrm{~W} / \mathrm{mK}\end{array}$ \\
\hline [39] & Water & $\begin{array}{l}\mathrm{TiO}_{2}, \mathrm{ZnO} \\
\text { and } \mathrm{Ag}\end{array}$ & $30-60$ & $0.25 \%$ & $\begin{array}{l}\text { Flowrate was } 1 \text { to } 3.5 \text { litre per second } \\
\text { Heat transfer enahcement for } \mathrm{TiO}_{2}, \mathrm{Ag} \text { and } \mathrm{ZnO} \text { was } \\
32 \%, 16 \% \text { and } 21 \% \text { repectively. }\end{array}$ \\
\hline [40] & Water & $\begin{array}{l}\mathrm{ZnO} \& \\
\mathrm{Al}_{2} \mathrm{O}_{3}\end{array}$ & - & 1 to $3 \%$ & $\begin{array}{l}\text { Thermal performance increased by increasing particle } \\
\text { concentration. }\end{array}$ \\
\hline [41] & Water & Diamond & $20-60$ & $\begin{array}{c}0.125,0.25,0.5 \\
0.75,1,1.25 \\
\end{array}$ & $\begin{array}{l}\text { Thermal conductivity } 25 \% \text { increased } \\
\text { Nanofluid was stable for } 14 \text { days }\end{array}$ \\
\hline [42] & Water & $\mathrm{Ni}$ & Up to 60 & $\begin{array}{c}0.1 \%, 0.3 \% \\
0.6 \%\end{array}$ & $\begin{array}{c}\text { Overall heat transfer enhanced } 38.6 \% \\
\text { Convective heat tranfer enhanced } 57.35 \%\end{array}$ \\
\hline [43] & Water & CNT & $30-80$ & - & $\begin{array}{c}\text { Surfactants were SDBS and GA } \\
\text { Overall heat transfer coefficient increased } 62.62 \%\end{array}$ \\
\hline [44] & Water & $\mathrm{Al}_{2} \mathrm{O}_{3}$ & $34-42$ & $0-5 \%$ & $\begin{array}{l}\text { Heat transfer improved } 75 \% \\
\text { Pressure drop increased } 8 \%\end{array}$ \\
\hline [45] & EG/ Water & $\mathrm{Al}_{2} \mathrm{O}_{3}$ & $-10-70$ & $0.01-0.5$ & $\begin{array}{l}\text { Convective heat tranfer enhanced } 22.7 \% \\
\text { Nanofluid prepared by using twe-step method }\end{array}$ \\
\hline
\end{tabular}




\begin{tabular}{c|c|c|c|c|c}
\hline Ref. & Basefluid & Particle & $\begin{array}{c}\text { Temperature } \\
\left({ }^{\circ} \mathbf{C}\right)\end{array}$ & Concentration & Remark \\
\hline$[46]$ & Water & $\begin{array}{c}\mathrm{CuO}, \\
\mathrm{Al}_{2} \mathrm{O}_{3}, \\
\mathrm{MgO}\end{array}$ & - & $\begin{array}{c}0.5 \text { and } 1.167 \\
\mathrm{~g} / \mathrm{L}\end{array}$ & $\begin{array}{c}\text { Efficiency increased } 83 \% \\
\text { Flowrate was } 5,8,11, \text { and } 14 \mathrm{~L} / \mathrm{min} \\
\text { Pressure drop was } 9 \%\end{array}$ \\
\hline$[47]$ & Water & $\mathrm{TiO}_{2}$ & $25-60$ & $0-2$ & $\begin{array}{c}\text { Sample was stable for } 30 \text { days } \\
\text { Thermal conductivity increased to } 0.78 \mathrm{~W} / \mathrm{m} . \mathrm{K}\end{array}$ \\
\hline$[48]$ & Water & $\mathrm{Al}_{2} \mathrm{O}_{3}-\mathrm{ZnO}$ & $25-65$ & $0.33-1.67$ & $\begin{array}{c}\text { Viscosity increased } 96.37 \% \\
\text { Specific heat transfer decreased } 30.12 \% \\
\text { Ultrasonication was } 3 \mathrm{~h}\end{array}$ \\
\hline$[49]$ & Water & $\mathrm{TiO}_{2}$ & $20-60$ & - & $\begin{array}{c}\text { Flowrate was } 0.1 \text { to } 0.5 \mathrm{~L} / \mathrm{min} \\
\text { Thermal conductivity enhanced } 12.4 \%\end{array}$
\end{tabular}

\section{Materials and Methods}

The present study was conducted in a manufactured double pipe carbon steel heat exchanger with an inner diameter of $37.5 \mathrm{~mm}$ and an outer diameter of $50.8 \mathrm{~mm}$. Thermometers were installed to measure the temperature at certain distances from the heat exchanger. The nanofluid's thermal properties were investigated. The nanofluid consists of aluminium oxide nanoparticles on water-based fluid consisting of a $1 \%$ volume fraction of aluminium oxide prepared in two steps and a hot inlet fluid temperature of $80^{\circ} \mathrm{C}$ and an inlet nanofluid of 20 ${ }^{\circ} \mathrm{C}$. Adding nanoparticles to the base fluid increases the adhesion and increases the thermal conductivity, which improves the overall heat transfer coefficient, reduces the boundary layer's thickness, and reduces the surface area required for heat transfer. The Brownian motion of nanoparticles led to higher heat transfer from the wall to the nanofluid. Increasing the volume of nanoparticles intensifies the mechanisms associated with increased heat transfer. Another advantage of using nanofluid is that the flow rate for the nanofluid is lower than the base fluid. Also, the pressure drop will not change much, which means that the nanofluid can transfer the same amount of energy at a lower flow rate that at the same flow rate, the volume of equipment is reduced. The schematic of the experimental setup is presented in Figure 5. This set-up consists of valves, flowmeters, tanks and pressure and temperature indicators.

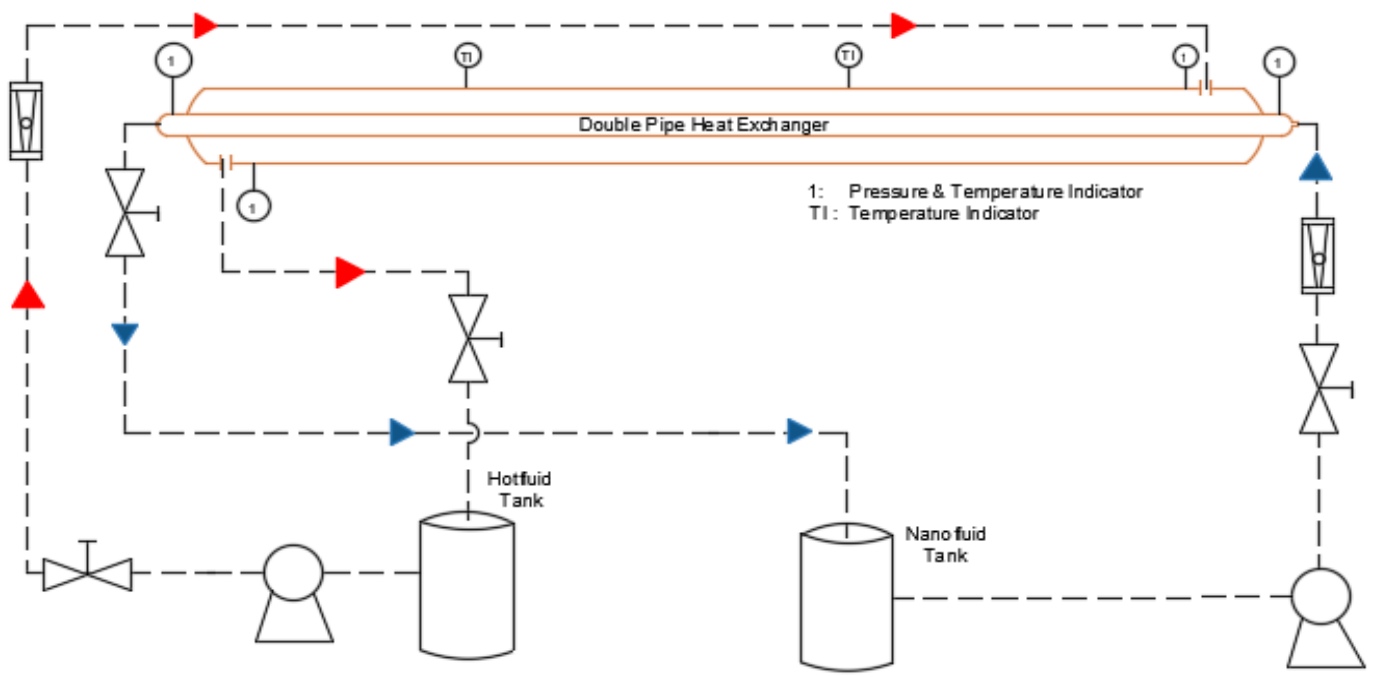

Figure 5. Schematic of set-up section.

\section{Results and Discussion}

The Nusselt number increases by increasing Reynolds and nanoparticle concentration. The maximum Nusselt number was obtained for the case where the hot fluid flowed in the outer tube, which was 25.44 and the highest percentage was $358 \%$. According to figure 6 , the 
highest overall heat transfer coefficient was $469.9 \mathrm{~W} / \mathrm{m}^{2} . \mathrm{K}$ for the case where the hot fluid flowed in the outer tube and its increase percentage was $253 \%$ and $144 \%$ for the hot fluid flow in the inner and outer tube, respectively, and this increase eventually reduced the heat transfer surface and the size of the heat exchanger. Also, by dispersing nanoparticles to the base fluid, the friction coefficient increases, which leads to an increase in the pressure drop, although this enhancement is negligible and does not cause any additional drop over the base fluid.

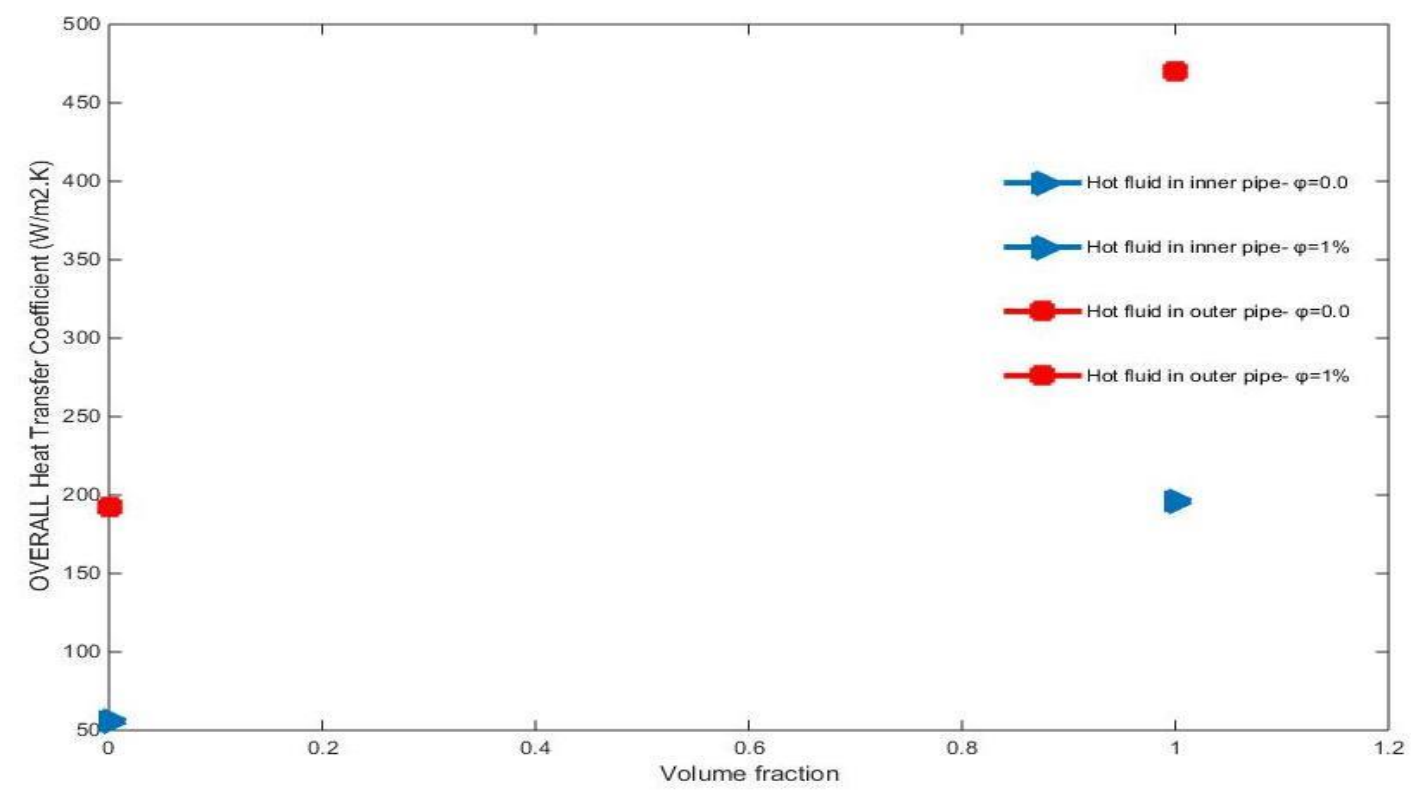

Figure 6. Overall heat transfer coefficient versus concentration.

It is shown in figure 7 that the highest convective heat transfer coefficient is 821.5 $\mathrm{W} / \mathrm{m}^{2}$.C for the case where the hot fluid has flowed in the outer pipe and also improvement in the convective coefficient is $94 \%$ and $308 \%$ for the hot tube in the inner and outer pipe respectively. The nanofluid heat transfer coefficient is expected to be a function of the thermal conductivity coefficient, nanofluid heat capacity, the flow, nanofluid concentration, dimensions, and the shape of these particles as well as the flow structure.

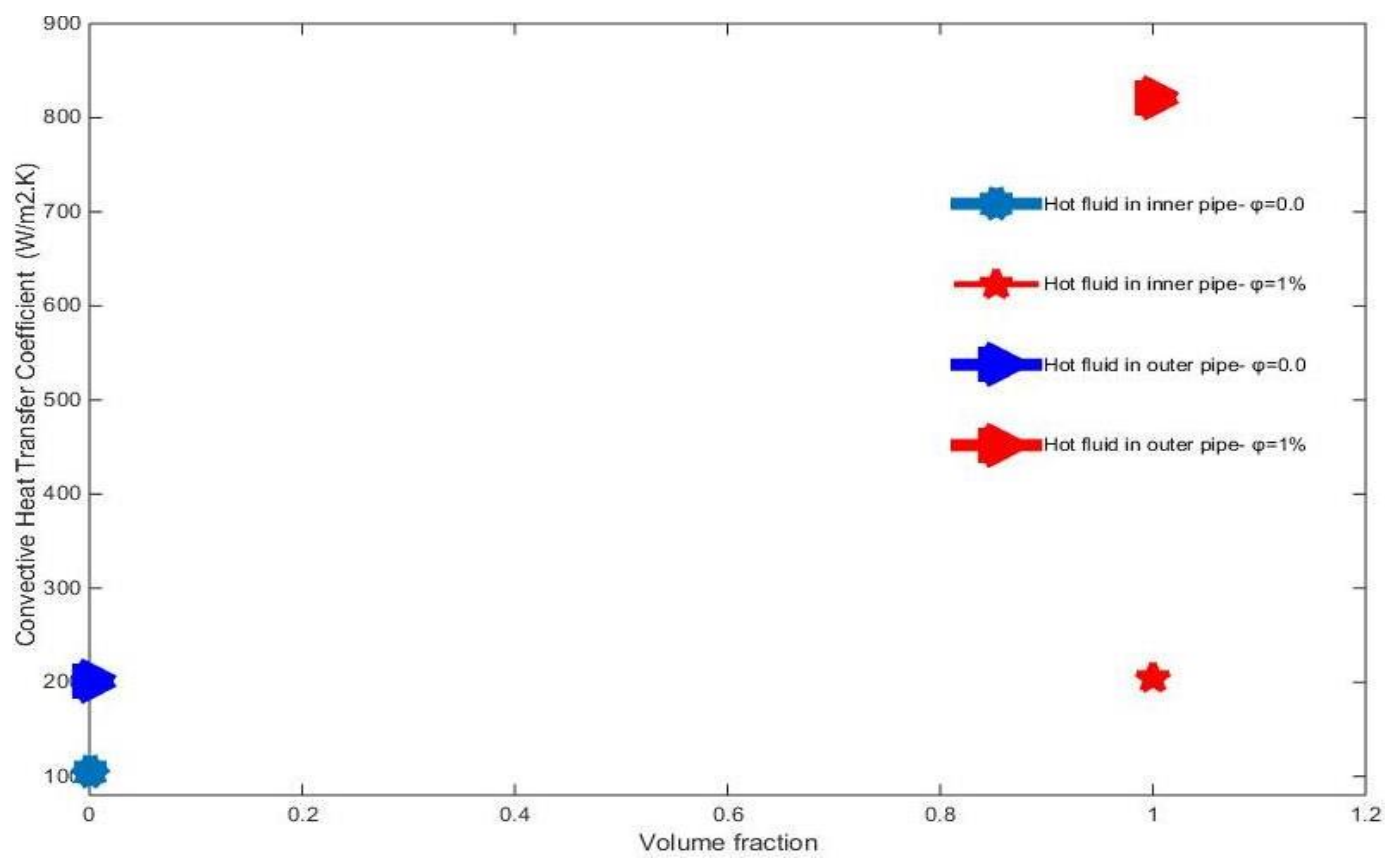

Figure 7. Convective heat transfer coefficient versus volume fraction. 
Figure 8 the change in the Nusselt number of nanofluid versus water-based fluid presented at Reynolds number for different volume fractions. As it is shown, the Nusselt number increases with increasing Reynolds number and volume fraction of nanoparticles. Any increase in the concentration of nanoparticles improves thermal conductivity and thus increases the heat transfer coefficient.

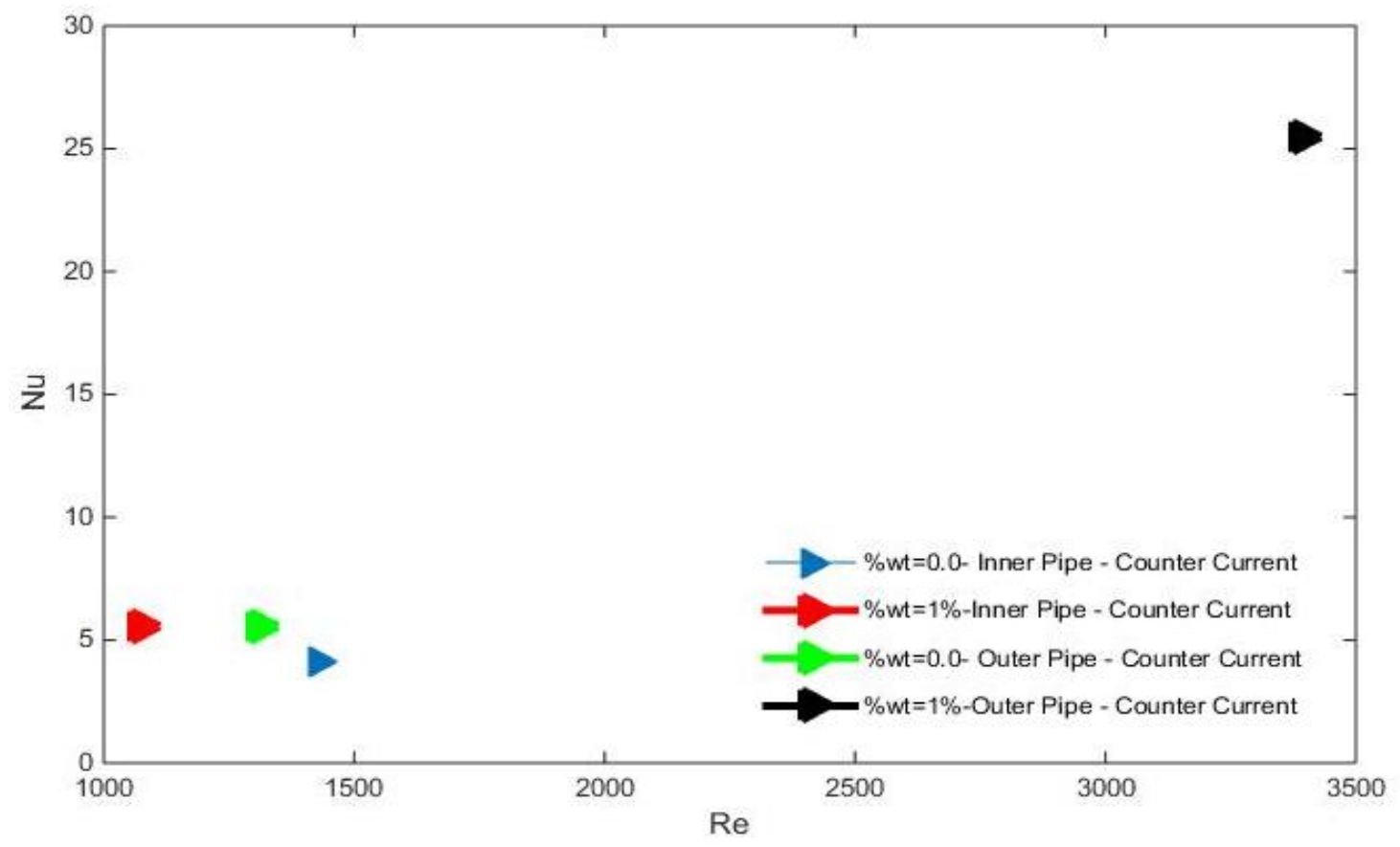

Figure 8. Nu number versus Re number.

\section{Conclusions}

The results obtained from the study on the heat transfer performance of nanofluids clearly showed that nanoparticles significantly increase heat transfer performance. Nanofluids also have higher heat transfer coefficients than base fluids at the same Reynolds numbers. A number of reports in the literature have shown that the heat transfer performance of nanofluids and the applications of nanofluids to enhance heat transfer are influenced by the thermophysical properties of nanofluids and the size of the particles, the shape of the particles, random motion, and fluid-particle interaction. Therefore, in this study, the heat transfer properties of aluminium oxide-water nanofluid in a heat exchanger and the role of nanoparticles in heat transfer improvement and reduce the heat exchanger size were studied. As a final result, when nanofluid flow into the inner pipe, the heat performance shows good results.

\section{Funding}

This research received no external funding.

\section{Acknowledgments}

This research has no acknowledgment.

\section{Conflicts of Interest}

The authors declare no conflict of interest. 


\section{References}

1. Choi, S.U.; Eastman, J.A. Enhancing thermal conductivity of fluids with nanoparticles; Argonne National Lab., IL (United States): 1995.

2. Akilu, S.; Baheta, A.T.; M.Said, M.A.; Minea, A.A.; Sharma, K.V. Properties of glycerol and ethylene glycol mixture based $\mathrm{SiO} 2-\mathrm{CuO} / \mathrm{C}$ hybrid nanofluid for enhanced solar energy transport. Sol. Energy Mater. Sol. Cells 2018, 179, 118-128.

3. Singh, J.; Dutta, T.; Kim, K.-H.; Rawat, M.; Samddar, P.; Kumar, P. 'Green' synthesis of metals and their oxide nanoparticles: applications for environmental remediation. Journal of Nanobiotechnology 2018, 16, 84, https://doi.org/10.1186/s12951-018-0408-4.

4. Porgar, S.; Vafajoo, L.; Nikkam, N.; Vakili-Nezhaad, G. A comprehensive investigation in determination of nanofluids thermophysical properties. J. Indian Chem. Soc. 2021, 98, https://doi.org/10.1016/j.jics.2021.100037.

5. Fakoya, M.F.; Shah, S.N. Emergence of nanotechnology in the oil and gas industry: Emphasis on the application of silica nanoparticles. Petroleum 2017, 3, 391-405, https://doi.org/10.1016/j.petlm.2017.03.001.

6. Cacua, K.; Ordoñez, F.; Zapata, C.; Herrera, B.; Pabón, E.; Buitrago-Sierra, R. Surfactant concentration and $\mathrm{pH}$ effects on the zeta potential values of alumina nanofluids to inspect stability. Colloids Surf. Physicochem. Eng. Aspects 2019, 583, 123960.

7. Hemmat Esfe, M.; Abbasian Arani, A.A.; Rezaie, M.; Yan, W.-M.; Karimipour, A. Experimental determination of thermal conductivity and dynamic viscosity of $\mathrm{Ag}-\mathrm{MgO} /$ water hybrid nanofluid. ICHMT 2015, 66, 189-195, https://doi.org/10.1016/j.icheatmasstransfer.2015.06.003.

8. Singh, R.; Sharma, A.; Dixit, A.; Tiwari, A.; Pramanik, A.; Mandal, A. Performance Evaluation of Aluminagraphene Hybrid Nano-cutting Fluid in Hard Turning. Journal of Cleaner Production 2017, 162, https://doi.org/10.1016/j.jclepro.2017.06.104.

9. Babar, H.; Ali, H.M. Towards hybrid nanofluids: Preparation, thermophysical properties, applications, and challenges. J. Mol. Liq. 2019, 281, 598-633, https://doi.org/10.1016/j.molliq.2019.02.102.

10. Simpson, S.; Schelfhout, A.; Golden, C.; Vafaei, S. Nanofluid Thermal Conductivity and Effective Parameters. Applied Sciences 2019, 9, https://doi.org/10.3390/app9010087.

11. Agarwal, R.; Verma, K.; Agrawal, N.; Duchaniya, R.K.; Singh, R. Synthesis, characterization, thermal conductivity and sensitivity of $\mathrm{CuO}$ nanofluids. Appl. Therm. Eng. 2016, 102, https://doi.org/10.1016/j.applthermaleng.2016.04.051.

12. Patel, H.E.; Sundararajan, T.; Das, S.K. An experimental investigation into the thermal conductivity enhancement in oxide and metallic nanofluids. JNR 2010, 12, 1015-1031, https://doi.org/10.1007/s11051009-9658-2.

13. Das, P.K. A review based on the effect and mechanism of thermal conductivity of normal nanofluids and hybrid nanofluids. J. Mol. Liq. 2017, 240, 420-446, https://doi.org/10.1016/j.molliq.2017.05.071.

14. Mechiri, S.K.; Vasu, V.; Babu, S. Thermal conductivity of Cu-Zn hybrid newtonian nanofluids: Experimental data and modeling using neural network. Procedia Engineering 2015, 127, 561-567.

15. Tahat, M.S.; Benim, A.C. Experimental analysis on thermophysical properties of $\mathrm{Al} 2 \mathrm{O} 3 / \mathrm{CuO}$ hybrid nano fluid with its effects on flat plate solar collector. 2017; 148-156.

16. Baby, T.T.; Ramaprabhu, S. Experimental investigation of the thermal transport properties of a carbon nanohybrid dispersed nanofluid. Nanoscale 2011, 3, 2208-2214, https://doi.org/10.1039/C0NR01024C.

17. Fal, J.; Cholewa, M.; Gizowska, M.; Witek, A.; Żyła, G. Dielectric Properties of Boron Nitride-Ethylene Glycol (BN-EG) Nanofluids. JEMat 2017, 46, 856-865, doi:10.1007/s11664-016-4971-x.

18. Yang, Y.; Grulke, E.A.; Zhang, Z.G.; Wu, G. Thermal and rheological properties of carbon nanotube-in-oil dispersions. JAP 2006, 99, 114307, https://doi.org/10.1063/1.2193161.

19. Shaikh, S.; Lafdi, K.; Ponnappan, R. Thermal conductivity improvement in carbon nanoparticle doped PAO oil: An experimental study. JAP 2007, 101, 064302, https://doi.org/10.1063/1.2710337.

20. Marquis, F.D.S.; Chibante, L.P.F. Improving the heat transfer of nanofluids and nanolubricants with carbon nanotubes. JOM 2005, 57, 32-43, https://doi.org/10.1007/s11837-005-0180-4.

21. Xie, H.; Lee, H.; Youn, W.; Choi, M. Nanofluids containing multiwalled carbon nanotubes and their enhanced thermal conductivities. JAP 2003, 94, 4967-4971, https://doi.org/10.1063/1.1613374.

22. Chopkar, M.; Sudarshan, S.; Das, P.K.; Manna, I. Effect of Particle Size on Thermal Conductivity of Nanofluid. Metall. Mater. Trans. A 2008, 39, 1535-1542, https://doi.org/10.1007/s11661-007-9444-7. 
23. Prasher, R.; Bhattacharya, P.; Phelan, P.E. Brownian-Motion-Based Convective-Conductive Model for the Effective Thermal Conductivity of Nanofluids. J. Heat Transfer 2005, 128, 588-595, https://doi.org/10.1115/1.2188509.

24. Philip, J.; Shima, P.D.; Raj, B. Enhancement of thermal conductivity in magnetite based nanofluid due to chainlike structures. ApPhL 2007, 91, 203108, https://doi.org/10.1063/1.2812699.

25. Xue, L.; Keblinski, P.; Phillpot, S.R.; Choi, S.U.S.; Eastman, J.A. Effect of liquid layering at the liquid-solid $\begin{array}{lllll}\text { interface on thermal } & \text { transport. }\end{array}$ https://doi.org/10.1016/j.ijheatmasstransfer.2004.05.016.

26. Hemmat Esfe, M.; Saedodin, S.; Mahian, O.; Wongwises, S. Thermophysical properties, heat transfer and pressure drop of $\mathrm{COOH}$-functionalized multi walled carbon nanotubes/water nanofluids. ICHMT 2014, 58, 176-183, https://doi.org/10.1016/j.icheatmasstransfer.2014.08.037.

27. Walvekar, R.; Faris, I.A.; Khalid, M. Thermal conductivity of carbon nanotube nanofluid-Experimental and theoretical study. Heat Transfer-Asian Research 2012, 41, 145-163, https://doi.org/10.1002/htj.20405.

28. Moldoveanu, G.; Minea, A.A.; Iacob, M.; Constanta, I.; Danu, M. Experimental study on viscosity of stabilized $\mathrm{Al} 2 \mathrm{O} 3$, TiO 2 nanofluids and their hybrid. Thermochim. Acta 2017, 659, https://doi.org/10.1016/j.tca.2017.12.008.

29. Sarafraz, M.M.; Hormozi, F.; Nikkhah, V. Thermal performance of a counter-current double pipe heat exchanger working with COOH-CNT/water nanofluids. Exp. Therm Fluid Sci. 2016, 78, 41-49, https://doi.org/10.1016/j.expthermflusci.2016.05.014.

30. Aghayari, R.; Maddah, H.; Zarei, M.; Dehghani, M.; Kaskari Mahalle, S.G. Heat Transfer of Nanofluid in a Double Pipe Heat Exchanger. International Scholarly Research Notices 2014, 2014, 736424, https://doi.org/10.1155/2014/736424.

31. Walvekar, R.; Siddiqui, M.K.; Ong, S.; Ismail, A.F. Application of CNT nanofluids in a turbulent flow heat exchanger. J. Exp. Nanosci. 2016, 11, 1-17, https://doi.org/10.1080/17458080.2015.1015461.

32. Chavda, D.N. Effect Of Nanofluid On Heat Transfer Characteristics Of Double Pipe Heat Exchanger: PartII: Effect Of Copper Oxide Nanofluid. International Journal of Research in Engineering and Technology 2015, 4, 688-696.

33. Peyghambarzadeh, S.M.; Hashemabadi, S.H.; Chabi, A.R.; Salimi, M. Performance of water based CuO and $\mathrm{A} 12 \mathrm{O} 3$ nanofluids in a $\mathrm{Cu}-\mathrm{Be}$ alloy heat sink with rectangular microchannels. Energy Convers. Manage. 2014, 86, 28-38, https://doi.org/10.1016/j.enconman.2014.05.013.

34. Yang, Y.; Zhang, Z.G.; Grulke, E.A.; Anderson, W.B.; Wu, G. Heat transfer properties of nanoparticle-influid dispersions (nanofluids) in laminar flow. IJHMT 2005, 48, 1107-1116, https://doi.org/10.1016/j.ijheatmasstransfer.2004.09.038.

35. Porgar, S.; Vafajoo, L.; Nikkam, N.; Vakili-Nezhaad, G. Physiochemical studies of functionalized MWCNT/transformer oil nanofluid utilized in a double pipe heat exchanger. CaJCh 2021, 99, https://doi.org/10.1139/cjc-2020-0297.

36. Vidhya, R.; Balakrishnan, T.; Suresh Kumar, B. Investigation on thermophysical properties and heat transfer performance of heat pipe charged with binary mixture based $\mathrm{ZnO}-\mathrm{MgO}$ hybrid nanofluids. Materials Today: Proceedings 2021, 37, 3423-3433, https://doi.org/10.1016/j.matpr.2020.09.284.

37. Li, X.; Wang, H.; Luo, B. The thermophysical properties and enhanced heat transfer performance of SiCMWCNTs hybrid nanofluids for car radiator system. Colloids Surf. Physicochem. Eng. Aspects 2021, 612, 125968.

38. Chawhan, S.S.; Barai, D.P.; Bhanvase, B.A. Investigation on thermophysical properties, convective heat transfer and performance evaluation of ultrasonically synthesized Ag-doped $\mathrm{TiO} 2$ hybrid nanoparticles based highly stable nanofluid in a minichannel. Thermal Science and Engineering Progress 2021, 100928, https://doi.org/10.1016/j.tsep.2021.100928.

39. Hozien, O.; El-Maghlany, W.M.; Sorour, M.M.; Mohamed, Y.S. Experimental study on thermophysical properties of $\mathrm{TiO} 2, \mathrm{ZnO}$ and $\mathrm{Ag}$ water base nanofluids. J. Mol. Liq. 2021, 334, 116128, https://doi.org/10.1016/j.molliq.2021.116128.

40. Salhi, J.-E.; Zarrouk, T.; Salhi, N. Numerical analysis of the properties of nanofluids and their impact on the thermohydrodynamic phenomenon in a heat exchanger. 2021, https://doi.org/10.1016/j.matpr.2021.02.365.

41. Alshayji, A.; Asadi, A.; Alarifi, I.M. On the heat transfer effectiveness and pumping power assessment of a diamond-water nanofluid based on thermophysical properties: An experimental study. Powder Technol. 2020, 373, 397-410, https://doi.org/10.1016/j.powtec.2020.06.068. 
42. Saleh, B.; Sundar, L.S. Experimental study on heat transfer, friction factor, entropy and exergy efficiency analyses of a corrugated plate heat exchanger using $\mathrm{Ni}$ /water nanofluids. International Journal of Thermal Sciences 2021, 165, 106935, https://doi.org/10.1016/j.ijthermalsci.2021.106935.

43. Singh, K.; Sharma, S.K.; Gupta, S.M. An experimental investigation of hydrodynamic and heat transfer characteristics of surfactant-water solution and CNT nanofluid in a helical coil-based heat exchanger. Materials Today: Proceedings 2021, 43, 3896-3903, https://doi.org/10.1016/j.matpr.2020.12.1233.

44. Gkountas, A.A.; Benos, L.T.; Sofiadis, G.N.; Sarris, I.E. A printed-circuit heat exchanger consideration by exploiting an Al2O3-water nanofluid: Effect of the nanoparticles interfacial layer on heat transfer. Thermal Science and Engineering Progress 2021, 22, 100818, https://doi.org/10.1016/j.tsep.2020.100818.

45. Choi, T.J.; Park, M.S.; Kim, S.H.; Jang, S.P. Experimental Study on the Effect of Nanoparticle Migration on the Convective Heat Transfer Coefficient of EG/Water-based A12O3 Nanofluids. IJHMT 2021, 169, 120903, https://doi.org/10.1016/j.ijheatmasstransfer.2021.120903.

46. Shafiey Dehaj, M.; Ahmadi, M.; Zamani Mohiabadi, M. Assessment of a heat pipe solar collector with nanofluids. Environ. Sci. Pollut. Res. Int. 2021, 28, 5316-5331, https://doi.org/10.1007/s11356-020-10797-x.

47. Zhang, H.; Qing, S.; Zhai, Y.; Zhang, X.; Zhang, A. The changes induced by pH in TiO2/water nanofluids: Stability, thermophysical properties and thermal performance. Powder Technol. 2021, 377, 748-759, https://doi.org/10.1016/j.powtec.2020.09.004.

48. Wole-Osho, I.; Okonkwo, E.C.; Kavaz, D.; Abbasoglu, S. An experimental investigation into the effect of particle mixture ratio on specific heat capacity and dynamic viscosity of Al2O3-ZnO hybrid nanofluids. Powder Technol. 2020, 363, 699-716, https://doi.org/10.1016/j.powtec.2020.01.015.

49. Hosseini, S.M.S. Assessment of $\mathrm{TiO} 2$ water-based nanofluids with two distinct morphologies in a U type evacuated tube solar collector. Appl. Therm. Eng. 2020, 182, https://doi.org/10.1016/j.applthermaleng.2020.116086. 